\title{
Technological complex as a factor for increasing the efficiency of professional training of future specialists in the construction
}

\author{
Ilfak Vildanov ${ }^{1}$ [00000003-1902-1621], and Rais Safin $^{1 *}{ }^{\text {[0000-0003-1864-7876] }}$ \\ ${ }^{1}$ Kazan State University of Architecture and Engineering, 420043, Zelenaya st., Kazan, Russia
}

\begin{abstract}
The construction industry plays a leading role in the Russian economy. Its innovative development is defined by highly qualified personnel, trained at educational institutions. The process of training such specialists requires integration of systemic, context-oriented, competenceoriented, personal and environmental educational approaches. The integration should act as a leading principle while designing all the components of the education process at technical universities. Within the context of the requirement defined by the Federal Educational Standards, we argue that the most promising solution should be the development of the technological complex, including its basic element i.e. the scientific and educational cluster aimed at every curriculum. This center must be equipped with up-to-date machinery that allows carrying out researches. The main goal of the research is to design the technological complex, allowing ensuring the professional and personal development of future graduates. The main result of the research lies in developing new basics aimed at creating and using the technological complex to train civil engineering students. The results can be used at technical universities while designing and creating scientific and educational centers.

Keywords: vocational education system, production system, technological complex, scientific and educational center, educational environment.
\end{abstract}

\section{Introduction}

The training of specialists for the innovative economy is impossible without the close interaction of education and production systems [1-14]. In his PhD thesis N. K. Chapayev [15] advocates the unification of pedagogy (education) and production. The emergence of education took place when a person mastered the process of making and using tools. This contributed to the birth of the technology of the simplest tools, their application, and the introduction of this technology for the transferring skills further down the genealogy line. This makes us conclude that a human being has both productive and educational nature. The interaction of education and production has further led to the introduction of technical terms to education.

\footnotetext{
*Corresponding author: safin_15_418@mail.ru
} 
Today, technical terms have been increasingly used in education. For example, N. K. Chapayev argues that there are such terms as: «educational production» (A. P. Sidelkowski, G. P. Schedrovitskiy, «production of personality» (A. G. Asmolov) [15].

By analogy with the «production», the terms of «educational processes», «educational technologies», etc. have appeared and become firmly established in educational science.

We believe that the term «complex» may be successfully used in educational studies.

A complex (from the Latin complexus, a combination), a set of objects or phenomena that make up one whole [16].

Russia's economic system uses the terms «industrial complex», «production complex» [17].

The economic (internet-linked) combination of enterprises in one industrial place makes an «industrial complex».

«Production complex» is defined as a planned large-scale territorial combination of enterprises and organizations of different branches of the national economy. They are united by a common economic, technological and organizational relationship [18].

The term has been used in educational studies. The work [19] describes the technological complex of further training of teachers in the implementation of environmental education. It consists of the following components: objective, content, activity, and result.

The other component of the technology complex is presented in monograph [20]. The components are based on (1) methods of increasing student learning in special construction and civil engineering subjects; (2) educational and creative tasks and cases; (3) play exercises and business games; (4) methods and tools for student learning.

In this work, the methods of increasing the training activities in all classes (the first component of the complex) are discussed. Thus, the increase is achieved by reading the lecture in the following ways: two lecturers of the department, or a lecturer together with the most proficient student. To enhance the student's work during lectures, the fast-track test will be carried out within 3-5 minutes, and the method of «engaging in dialogue» with the lectures was also used.

The practical lessons include the work of students in «creative groups together with teachers». The group consists of 2-3 teachers and 10-12 students. At such lessons, the reconstruction methods of the existing buildings and structures have been developed to intensify the efficiency of their work.

The increase in the training activities of the students was achieved through the establishment of a «student scientific and production unit», in the project activity (course design, in the execution of the final qualified works)-the method of «continuous exchange and diploma design», etc.

The technology of the task approach (the second component of the complex) was used in the solution of educational and creative tasks. They were composed of more than 1500 students according to 12 classification groups [20]. Improvement in the effectiveness of training was achieved in the application of situational tasks and cases.

The didactic, role, and business games were developed and applied in the study of special disciplines (the third component of the complex). There were more than 20 of them. All the teachers of the department have used them.

The current test control and the final control were conducted to determine the level of improvement of the training.

It should be noted that the technological complex was used during the period of training of civil engineers according to state educational standards when the result of the training was evaluated in knowledge and skills. In modern conditions, we are preparing according to the Russian Federal Educational Standards of the Third Generation (FES3++), and the result is assessed in the established universal and professional competencies. The 
requirements for the organization of the educational process have also changed, allowing for the development of a technological facility for building projects within the context of FES3++.

\section{Methods}

In the process of work the analysis of regulatory documents, educational sources, and methodological approaches to educational research was carried out. The methodological basis for the systemic integration of professional construction education lies in the synthesis of five approaches: system, competent, personality-oriented, contextual, and environmental.

\section{Results and discussion}

In the context of the implementation of FES3++ along with the requirement to take into account the requirements of professional standards in the design of educational programs, the development of a more modern technological complex is needed. This complex has been developed and consists of the following structural components: target, content, technological, environmental, and result.

The objective component. The main objective of the technological complex is the training of specialists with professional, communicative skills and personal qualities, capable and ready to solve problems of design, construction of structures, operation of buildings and structures with the use of energy resource-saving materials.

$A$ descriptive component. The requirements for the maintenance of the construction profile shall be based on:

- Taking into account the achieved level of development of science, technology, production, the general cultural features of society and reflection of prospects, trends in social and scientific and technological progress, changes in the content of work;

- Reflection of the increasing role of science in the development of productive forces and improvement of industrial relations;

- The integrity of the content of higher education, when all its elements are selected, structured, and integrated according to the main objectives of higher education;

- The principles of continuity, integration, and differentiation, humanization, and democratization of education [10].

Technology component. The component includes training technologies that are used in the educational process of the civil engineering majors. The education of future civil engineers is based on the use of problematic, modular, personal-oriented, contextual, and concentrated learning technologies.

The basic component of the technological complex is, in our opinion, the environmental one, developed in the form of Scientific and Educational Centers (SEC's) in all areas of construction training.

The selection of SEC as a basic component is justified by the achievement of systematic integration of future graduates into SEC within the context of designing, development, and implementation of their projects.

Designing, construction, and implementation of SEC were carried out based on the integration of systemic, complex, contextual, and activity approaches.

The means of instruction in scientific and educational centers are a kind of educational activity for students. We define this activity as the first methodological basis for the study of special construction disciplines. 
The following methodological framework for the establishment of SEC is the purpose, objectives, and content of professional disciplines. They are known to determine the structure, presentation, location, and use of the means of education.

The methods and organizational forms of training (e. g. business, virtual games) are the third methodological basis for the design, creation, and use of SEC.

In the system of means of vocational training within the context of construction subjects, the subsystem of the means of their education plays a main role. The components of the subsystem contribute to the formation and development of basic concepts.

The teaching equipment should be seen in connection with the subsystems: technological lines, installations, computers, and other office equipment along with the scientific organization of the work of the teacher and students. The interrelationships of the three subsystems form SEC, which makes it a coherent, dynamic, open system, i.e. when new construction technologies, equipment, and materials are available, they can be placed in SEC. Thus, the components of SEC will be comprised of: a set of didactic means and equipment, a zone of students' location, a teacher's work area, a zone of training equipment, a storage room of equipment and devices, office equipment, the location of lighting, design of the interior of that meets functional requirements.

The integration of the content of the training is ensured in the study of the various technological schemes created based on the integration of natural sciences and technical disciplines.

The location of furniture allows organizing business and role games, methods of brainstorming, discussions, and training.

The use of these techniques involves integration and learning technologies (tasking, problem, etc.) [6].

SEC integrates the following environments: educational, professional, socializing, research, and educational which provide personal and professional development for future professionals.

Thus, the formation of the personal sphere is achieved by the creation of a professional one.

SEC uses textbooks, information materials received through the Internet, which leads to the integration of the environment, and then the forms of training (individual, group, frontal, etc.).

SEC provides for the possibility of conducting training, laboratory, and research for bachelors, masters and postgraduate students, leading to the integration of educational levels.

SEC holds joint seminars with specialists in the construction industry, heads of the companies ' training centers, with the participation of students, whereas the center's teachers carry out training in leading firms, which ensures the integration of corporate and formal education. Thus, students are included in the entire spectrum of public relations in the industry.

Analysis of work by N.A. Alekseyev, A.G. Asmolov, A.A. Verbitskiy, E.F. Zeyer, G.I. Ibragimov, L.N. Mitina, V.V. Serikov, E.V. Tkachenko. N.K. Chapayev, I.S. Yakimanskaya, and other researchers allow us to formulate the following conceptual provisions for the technological complex of training of future specialists in the construction industry:

- The subject of education and its personal and professional development form a strategic goal of realization of the technological complex in the educational process of the technical university;

- The necessary conditions for the development of the abilities of the trainees, their professional development, will ensure in some way a designed technological complex that takes into account the individual and psychophysiological features of the students; 
- The basic element of the technological complex is the scientific and educational centers, which ensure systematic integration of the components of the educational space, aimed at for the formation of practical skills (competencies) and experience of activity following their majors;

- The scientific and educational center (architectural, spatial, substantive, ergonomic, etc.) forms an integrative environment for the creative development of the trainees, stimulating its individual and collective activities; the criteria for training in SEC are universal and professional competencies developed following the FES3++;

- The conditions for the professional development of the trainees are provided by teaching staff, implicating their personal and social, and professional characteristics in the training content and integrating them into the technological complex.

The technological complex of civil engineering majors is designed with the support of the following principles: system, ergonomic, flexibility, optimization, and quality.

The complex has many overlays that interact with each other, having relations and connections, which is typical of the principle of consistency.

The conformity of the complex with temporary, spatial, logistical, safe, sanitary, and other conditions of training sets the principle of ergonomics.

The modern construction industry is characterized by frequently changing technologies, materials and equipment, resources, and new requirements for the training of specialists. Adapting the technological complex to the new changing requirements of the building complex is allowed by the principle of flexibility.

Improving the efficiency of training from each component of the technology complex, with the least cost, ensures the best value for money.

Compliance of all elements of the technological complex with the standards of the FES3++ is achieved by constant monitoring at all stages of the designing and implementation of the complex and is established by the principle of quality.

The technology complex requires conceptual justification. The following humanistic and personal aspects of domestic and foreign educational theories and systems were adopted as a basis for the development of the concept of the technological complex for the training of future construction engineers:

In the course of the teaching process, a humane, respectful attitude to the trainees must be ensured;

The study has defined the development of the intellectual and spiritual capacities of which is directed at the entire educational process as the highest independent value;

- The following priorities have been identified as the main priorities of the education process: the development of the personality of the trainees, their unique identity, creativity, thinking, spacious mind, capacity for active and independent activity, the realization of the natural, free development of the trainees;

- The creative activity of the subject and the implementation of the types of training activities, developing thinking, contribute to the formation of the personality of the trainees; - In the process of teaching the teacher must rely on the subjective experience of the individual, which will enable targeted assistance along with individualized and differentiated education.

We believe that these provisions can be taken into account in the development of our technological complex.

The result component. The final performance component reflects the effectiveness of the educational process, the level of competence, and the personality of graduates of the university. 


\section{Conclusions}

The component composition of the technological complex for the training of future civil engineers industry was developed. The characteristics of the components are given. A basic component is defined i.e. introduction of SEC, which allows forming professional competencies and personal qualities of graduates, to increase the motivation of special construction disciplines. Thus, the results of the study motivation according to the method of T. D. Dubovitskaya 239 students from the Institute of Building Technology and Engineering Systems have shown that the motivation to study major disciplines has increased from $67.4 \%$ to $82.2 \%$ (which makes the difference of $14.8 \%$ ). The educational experiment within the context of «Civil engineering mechanics» subject aimed at the introduction of the technological complex showed better results in the pilot groups compared to the control group. The number of «good» and «excellent» students has increased by $12 \% .84 \%$ of students positively assessed the concentrated technology of education (186 students participated in the experiment).

\section{References}

1. R. Safin, E. Korchagin, G. Zagidullina, I. Vildanov, D. Sharafutdinov, R. Abitov, The integration process of the formation and development of the building educational cluster, Izvestija KSUAE, 4 (22), 520-529 (2012)

2. E. Korchagin, R. Safin, Integration as the basis of level vocational education in the scientific and educational cluster, Higher education in Russia, 6, 19-25 (2013)

3. E. Korchagin, R. Safin, P. Osipov, L. Yarullina, Personal development potential of professional training of future specialists, Professional education in Russia and abroad 1(13), 24-31 (2014)

4. V. Suchkov, R. Safin, E. Korchagin, I. Aituganov, Interaction of vocational education and production as a factor in the modernization of the training of competent specialists, Higher education in Russia, 12, 19-22 (2008)

5. E. Korchagin, I. Aituganov, L. Samoldina, R. Safin, Higher education institution and industrial enterprise: readiness for interaction, Higher education in Russia, 4, 138-143 (2011)

6. R. Safin, E. Korchagin, On the Quality of Vocational Training of Specialists: Why Russian Employers Are Not Satisfied with Them? Middle-East Journal of Scientific Research, 16(8), 1094-1099 (2013) DOI: 10.5829/idosi.mejsr.2013.16.08.11970

7. E. Korchagin, R. Safin, I. Vildanov, R. Abitov, Educational cluster as the element of Russian professional education system, Life Science Journal, 12(12s), 845-849 (2014)

8. A. Lunev, R. Safin, E. Korchagin, D. Sharafutdinov, T. Suchkova, L. Kurzaeva, S. Nikishina, N. Kuznetsova, The Mechanism of Industrial Educational Clusters Creation as Managerial Entities of Vocational Education, International Review of Management and Marketing, 6(S2), 166-171 (2016)

9. R. Safin, E. Korchagin, T. Suchkova, I. Vildanov, R. Abitov, The method of designing objectives and content of professional education in technical higher educational institutional based on professional standards, Espacios, 39(17), 21 (2018)

10. R. Khairutdinov, R. Safin, E. Korchagin, F. Mukhametzyanova, A. Fakhrundinova, S. Nikshina, The Content of Educational Programs in Technical Universities: Quality of Applying the Modern Professional Standards, International Journal of Instruction, 12(1), 357-370 (2019)

11. R. Safin, E. Korchagin, Vocational Training of Russian Students within Educational Cluster, Review of European Studies, 7(5), 168-174 (2015) DOI: 10.5539/res.v7n5p168 
12. R. Safin, E. Korchagin, I. Vildanov, R. Abitov, N. Kora, V. Nigmetzynova, Pedagogical Conditions of Students Independent Readiness Formation for Educational Cognitive Activity, Asian Social Science, 11(4), 269-274 (2015) DOI: 10.5539/ass.v11n4p269

13. R. Safin, A. Shaidullina, I. Muskhanova, T. Yusupkhadzhieva, I. Dzhamalkhanova, F. Mezhidova, V. Nigmetzyanova, L. Akhmetov, Innovative Entrepreneurship in Education: A New Look in the Students Training Content and Existing Problems, International Review of Management and Marketing, 6(S2), 51-56 (2016)

14. L. Akhmetov, O. Kirillova, T. Kirillova, A. Varlamov, S. Kashina, R. Safin, E. Leonova, I. Sharonov, The Managerial Mechanism of Future Competitive Technical Specialists, Vocational Training: The Russian Experience International Review of Management and Marketing, 6(S2), 34-39 (2016)

15. N. Chapaev, Theoretical and methodological foundations of pedagogical integration: (Diss. ... doct. ped. Sciences, 13.00.01., Ekaterinburg, 492, 1998)

16. Big encyclopedic dictionary (Great Russian Encyclopedia, St. Petersburg, Norint)

17. D. Morkovkin, 2010 Industrial complex of the region as an object of management, Macroeconomics, 5, 97-101 (1997)

18. M. Bandman, O. Bandman, T. Esipova, Territorial production complexes: forecasting the formation process using a Petri net (Novosibirsk, Science, 297, 1990)

19. N. Nesgovorova, Technological complex of retraining teachers for the implementation of environmental education, Bulletin of the Kurgan State University Series: Natural Sciences, 15, 23-27 (2009)

20. V. Suchkov, R. Safin, T. Suchkova, Technological complex for training a competent engineer in the construction specialty (Kazan, KGASU, 188, 2011) 